\title{
Evaluasi Kinerja Operasi Sistem Anaerobik Tipe Fixed Bed untuk Pengolahan Limbah Cair Industri Tahu menjadi Biogas di Kota Probolinggo
}

\section{Operation of Fixed Bed Anarobic System for Tofu Liquid Waste Treatment in Probolinggo City}

\author{
PRASETYADI ${ }^{1}$, LARAS ANDRIA WARDANI ${ }^{2}$, HARYOTO KUSNOPUTRANTO ${ }^{2}$ \\ ${ }^{1}$ Pusat Teknologi Lingkungan, Badan Pengkajian dan Penerapan Teknologi, \\ Gedung Geostech 820, Kawasan Puspiptek, Serpong, Tangerang Selatan, 15314 \\ ${ }^{2}$ Sekolah Ilmu Lingkungan, Universitas Indonesia \\ prasetyadi@bppt.go.id
}

\begin{abstract}
Every process manufacture of tofu generally produces wastes, both solid and liquid. Solid waste can be utilized as animal feeds or raw materials for other industries, whereas the waste water that is usually disposed directly to the environtment may cause many problems. Actually, the liquid waste can be processed to produced biogas by using an anaerobic Fixed Bed reactor. The objective of this research is to examine the optimation process of organic material degradation of liquid wate from tofu industry using anaerobic Fixed Bed reactor. The research method is divided into two phases: first, inoculation process and adaptation process waste water tofu industry. The results obtained in this study was the establishment of anaerobic Fixed Bed reactor with capacities is $43 \mathrm{~m}^{3}$. Maximum performance capability of the reactor was on the 39th days with $7.700 \mathrm{~m}^{3}$ /day of loading rate, Hydraulic retention time was 4,5 days, while the maximum biogas production resulted from liquid waste process was $35.158 \mathrm{~L} /$ day, average persentation content of $\mathrm{CH}_{4}$ was $65 \%$, efficiency $\mathrm{COD}$ from the waste water treatment of tofu industry was $87,7 \%$, average $\mathrm{pH}$ effluent was 6,5 , and $1 \mathrm{~g}$ COD can produce $0,51 \mathrm{~L}_{\text {of }} \mathrm{CH}_{4}$
\end{abstract}

Keywords: Wastewater, Anaerobic, Fixed bed, Tofu industry

\begin{abstract}
ABSTRAK
Setiap proses pembuatan tahu secara umum menghasilkan limbah yaitu limbah padat dan limbah cair. Limbah padat yang dihasilkan dari industri tahu dapat digunakan sebagai pakan ternak atau dijual sebagai bahan baku industri lain, sedangkan limbah cair biasanya langsung dibuang sehingga menyebabkan masalah lingkungan. Pada dasarnya limbah cair industri tahu dapat diolah menjadi produk yang bermanfaat. Pada penelitian ini limbah cair industri tahu diolah menjadi biogas dengan menggunakan reaktor anaerobik tipe Fixed Bed. Tujuan dari Penelitian ini adalah untuk mengkaji dan mengatur variabel operasi reaktor tersebut agar berkinerja optimal dalam mendegradasi bahan organik yang terkandung dalam limbah cair industri tahu. Metode penelitian yang dilakukan terbagi menjadi dua tahapan yaitu proses inokulasi dan proses adaptasi limbah cair industri tahu. Hasil yang diperoleh pada penelitian ini adalah terbangunnya reaktor anaerobik tipe Fixed Bed dengqan kapasitas $43 \mathrm{~m}^{3}$. Kemampuan kinerja maksimal reaktor berada pada hari ke-39 dengan pengisian umpan limbah sebanyak 7.700 liter/hari, waktu tinggal 4,5 hari, sedangkan volume produksi biogas maksimum yang dihasilkan dari pengolahan limbah cair tahu ini adalah 35.158 Liter/hari, rata-rata nilai metana adalah $65 \%$, effisiensi COD yang diperoleh dari pengolahan limbah cair industri tahu ini adalah $87,7 \%$, nilai rata-rata $\mathrm{pH}$ effluent adalah 6,5, dan $1 \mathrm{~g}$ COD dapat menghasilkan 0,51liter gas metana
\end{abstract}

Kata Kunci: Limbah cair, Anaerobik, Fixed bed, Industri tahu

\section{PENDAHULUAN}

\subsection{Latar Belakang}

Tahu adalah salah satu makanan favorit masyarakat Indonesia dan memiliki harga yang terjangkau untuk semua golongan masyarakat. Oleh karena itu keberadaan industri tahu tersebar hampir di seluruh pelosok Indonesia.
Jumlah industri tahu di Indonesia adalah sekitar 84.000 unit usaha, dengan kapasitas produksi lebih dari 2,56 juta ton per tahun ${ }^{(1)}$. Dari data industri, $80 \%$ dari jumlah industri tahu berada di Pulau Jawa ${ }^{(1)}$. Disisi lain, setiap proses pembuatan tahu menimbulkan masalah lingkungan yaitu dihasilkannya limbah padat dan limbah cair. Limbah padat yang dihasilkan dari industri tahu dapat digunakan sebagai pakan 
ternak atau dijual sebagai bahan baku industri lain, sedangkan limbah cair yang dihasilkan biasanya langsung dibuang ke lingkungan.

Sebagian besar industri tahu masih belum memiliki instalasi pengolahan limbah cair, dan limbah cair dari industri tahu tersebut biasanya langsung dibuang ke badan air (2). Kurangnya kesadaran akan pentingnya menjaga kualitas lingkungan, dan keterbatasan biaya dalam pembuatan IPAL, pengolah limbah merupakan faktor yang mendorong para pengrajin tahu untuk membuang limbah produksinya secara langsung ${ }^{(3)}$. Disisi lain Kementerian Lingkungan Hidup telah mengeluarkan Peraturan Pemerintah No. 5 Tahun 2014 tentang Baku Mutu Air Limbah (BMAL), dan pada lampiran XVIII terdapat BMAL bagi usaha dan/atau kegiatan pengolahan kedelai, khususnya industri tahu dengan nilai ambang batas yang diperbolehkan yaitu COD sebesar $300 \mathrm{mg} / \mathrm{l}$ dan pH sebesar 6-9(4).

Limbah industri tahu mengandung banyak senyawa organik seperti protein $40-60 \%$, karbohidrat $25-50 \%$ dan lemak $10 \%{ }^{(5)}$. Berdasarkan penelitian Kim, Lee, dan Kim di Daejeon, Korea pada tahun 2011, limbah cair industri tahu memiliki kandungan Total Solid (TS) sebesar $43 \mathrm{~g} / \mathrm{l}$, Volatile Solid (VS) sebesar 41,3 g/l, Chemical Oxygen Demand (COD total) sebesar 82,1 $\mathrm{g} / \mathrm{l}$, dan $\mathrm{pH}$ sebesar $5,6^{(6)}$. Hal tersebut membuktikan bahwa kandungan limbah cair tahu telah melewati ambang batas yang diperbolehkan. Alkyol tahun 2012 menyatakan bahwa tingginya angka COD dapat membahayakan ikan dan menngkontaminasi rantai makanan apabila dibuang langsung ke saluran pembuangan tanpa diolah terlebih dahulu(7). Oleh karena itu untuk menurunkan kandungan organik tersebut maka diperlukan perlakuan khusus terlebih dahulu agar limbah cair industri tahu tersebut dapat memenuhi standar baku mutu yang telah ditetapkan.

Dalam upaya untuk meningkatkan kualitas lingkungan hidup perlu dilakukan strategi pada penanganan limbah industri tahu yang dapat menghasilkan manfaat. Salah satu strategi penanganan limbah yang dapat dilakukan pada industri tahu adalah membuat instalasi pengolahan menggunakan sistem anaerobik. Proses degradasi anaerobik merupakan proses fermentasi bahan organik oleh aktivitas bakteri anaerob pada kondisi tanpa oksigen bebas dan merubahnya dari bentuk tersuspensi menjadi terlarut dan biogas ${ }^{(8)}$. Pengolahan limbah secara anaerobik dapat diartikan sebagai proses biokimia yang menghasilkan biogas dengan merubah bahan organik kompleks menjadi sumber energi terbarukan ${ }^{(9)}$. Proses pengelohan anaerobik dapat memberikan keuntungan lebih dibandingkan pengolahan secara aerobik ${ }^{(10)}$, diantaranya yaitu:

- Proses anaerobik tidak membutuhkan energi untuk aerasi, sehingga mengurangi biaya pada proses pengolahannya

- Lumpur atau sludge yang dihasilkan lebih sedikit dari proses aerobik.

- Bahan pencemar berupa bahan organik yang dapat terbiodegradasi hampir semuanya dikonversi ke bentuk biogas (gas metana) yang mempunyai nilai kalor tinggi dan dapat digunakan sebagai subtitusi sumber energi.

Komposisi gas metana yang dihasilkan sangat bergantung dari kandungan bahan organik limbah cair industri tahu yang dapat didegradasi melalui proses anaerobik, diantaranya karbohidrat, lemak, dan protein. Proses pengolahan limbah secara anerobik terdiri atas proses hidrolisis, acidogenesis, asetogenesis, dan metanogenesis. Reaksi kimia berdasarkan proses degradasi senyawa organik dengan bakteri metanogenesis adalah ${ }^{(11)}$.

$4 \mathrm{H}_{2}+\mathrm{HCO}_{3}{ }^{-}+\mathrm{H}^{+} \rightarrow \mathrm{CH}_{4}+3 \mathrm{H}_{2} \mathrm{O}$

Acetate $+\mathrm{H}_{2} \mathrm{O} \rightarrow \mathrm{CH}_{4}+\mathrm{HCO}_{3}$

Metanaol $\rightarrow 3 / 4 \mathrm{CH}_{4}+1 / 4 \mathrm{HCO}_{3}{ }^{-}+1 / 4 \mathrm{H}^{+}+1 / 4 \mathrm{H}_{2} \mathrm{O}$

Hasil degradasi komponen utama buangan limbah akan menghasilkan konsentrasi gas metana adalah sebagai berikut $50 \% \quad \mathrm{CH}_{4}$ berasal dari karbohidrat, $68 \% \mathrm{CH}_{4}$ berasal dari lemak dan $70 \% \mathrm{CH}_{4}$ berasal dari protein ${ }^{(12)}$.

Menurut Weiland tahun 1987 reaktor tipe Fixed Bed adalah salah satu metoda terbaik pengolahan secara anaerobik untuk limbah dengan konsentrasi tinggi (12). Pengolahan secara anaerobik menjadi lebih menguntungkan ketika influentnya memiliki konsentrasi yang tinggi ${ }^{(13)}$. Reaktor tipe Fixed Bed adalah reaktor yang dilengkapi dengan material penyangga ${ }^{(14)}$. Fungsi dari material penyangga/support material tempat menempel mikroba atau bakteri, sehingga mikroba tidak ikut terbawa cairan sisa buangan atau effluent yang keluar dari reaktor ${ }^{(15)}$. Pada penelitian ini, material penyangga yang digunakan adalah bambu. Berdasarkan hasil percobaan Cao et al., potongan bambu merupakan material penyangga yang cukup efektif sebagai tempat menempelnya bakteri ${ }^{(16)}$. Bambu dapat menghasilkan biofilm yang tebal atau meningkatkan kepadatan pertumbuhan bakteri dalam reaktor, karena stuktur permukaan bambu yang berserabut dapat menghadang bahan organik termasuk bakteri(16). Selain itu, material penyangga bambu juga tidak dapat ikut teruraikan dalam proses anaerobik serta potongan bambu dapat dimanfaatkan lebih dari 10 tahun $^{(17)}$. Bakteri-bakteri anaerobik yang menempel pada material penyangga akan 
mendegradasi kandungan bahan organik limbah cair tahu menjadi biogas. Biogas yang dihasilkan dapat dimanfaatkan oleh masyarakat sekitar industri tahu untuk mensubtitusi pemakaian energi fosil (LPG, minyak tanah, dan kayu bakar) pada kegiatan memasak seharihari.

Pengolahan limbah cair tahu dengan menggunakan reaktor anaerobik tipe Fixed Bed dan bambu sebagai material penyangga ini diharapkan dapat membantu mengurangi beban pencemar di lingkungan, dan dihasilkannya biogas yang memiliki manfaat ekonomi. Penilitian ini, diharapkan dapat diterapkan dan digunakan oleh industri-industri lainya yang memiliki limbah dengan konsentrasi tinggi.

\subsection{Tujuan Penelitian}

Tujuan Penelitian ini adalah untuk mencari kinerja optimal degradasi bahan organik limbah cair industri tahu dari pengolahan limbah secara anaerobik dengan menggunakan reaktor tipe Fixed Bed.

\section{BAHAN DAN METODE}

\subsection{Tempat dan Waktu Penelitian}

Lokasi penelitian berada di industri tahu CV. Promatun Aroyyan, JL. Raya Kedung Asem 555/A, RT 2 RW 7, Kelurahan Kedung Asem, Kecamatan Wonoasih, Kota Probolinggo dengan kapasitas produksi sebesar 500 - 700 $\mathrm{kg}$ kedelai per hari. Penelitian ini dilakukan pada tahun 2014 dan 2015.

\subsection{Bahan}

Persiapan bahan dan peralatan utama yang dilakukan dalam pengolahan limbah cair industri tahu ini meliputi; persiapan penyaluran limbah cair yang akan diolah, lokasi (lahan) pembuatan reaktor, gas holder, dan potongan bambu sebagai material penyangga. Selain itu, peralatan analisa harian lapangan juga diperlukan seperti termometer, $\mathrm{pH}$ meter, metana tester, dan flow meter biogas.

\subsection{Metode}

Limbah cair industri tahu diolah dengan menggunakan reaktor anaerobik tipe Fixed Bed yang berbentuk tabung yang dilengkapi dengan pipa saluran masuk limbah dan pipa pengeluaran. Pipa pengeluaran dibagi menjadi dua yaitu pipa pertama untuk mengalirkan produk biogas yang dihasilkan dan pipa kedua untuk mengeluarkan effluent setelah proses pengolahan limbah cair. Biogas yang dihasilkan oleh reaktor anaerobik akan dialirkan ke arah gas holder melalui alat flow meter biogas, dan dicatat setiap volume kenaikan biogas per hari. Biogas yang ditampung di dalam gas holder akan diukur konsentrasi kandungan gas metananya dengan menggunakan alat metana tester.

Reaktor anaerobik tipe Fixed Bed ini diisi dengan potongan bambu sebagai material penyanga dan dioperasikan pada suhu mesofilik atau suhu ruang dengan sistem pola aliran up flow. Prinsip pola aliran sistem up flow adalah substrat umpan masuk melalui dasar reaktor yang kemudian terdistribusi diantara material penyangga dan keluar pada bagian atas ${ }^{(12)}$. Reaktor dengan sistem up flow akan mempunyai biomassa yang terperangkap didalam rongga-rongga diantara material penyangga, kadang kala mencapai $70 \%$ dari total akumulasi biomassa ${ }^{(18)}$. Akumulasi bakteri yang terjadi di material penyangga, dapat mempermudah bakteri utuk menempel pada permukaan material penyangga. Sketsa reaktor dapat dilihat pada Gambar 1.

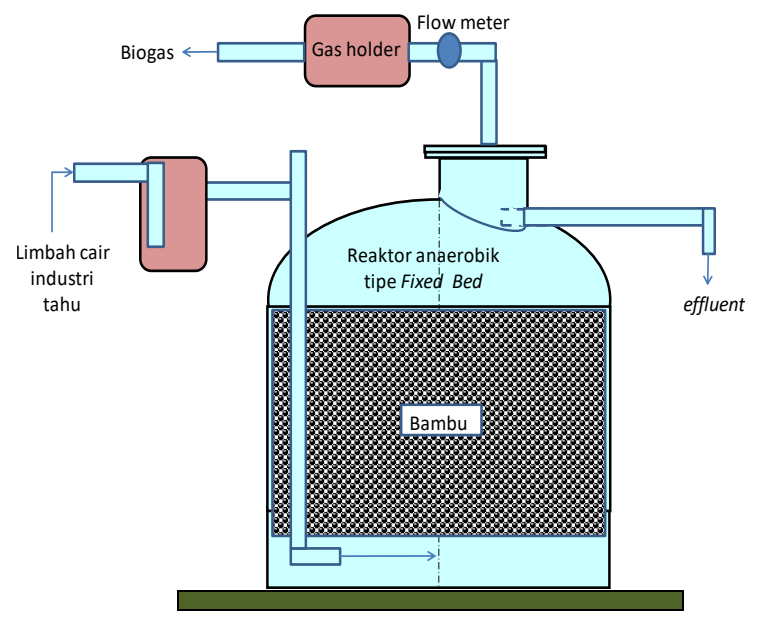

Gambar 1. Sketsa reaktor anaerobik tipe Fixed Bed

Volume ruang pada reaktor tipe Fixed Bed ini terbagi menjadi dua yaitu volume total reaktor dan volume kerja efektif reaktor. Volume total reaktor adalah volume keselurahan reaktor, sedangkan volume kerja efektif adalah volume reaktor yang sudah dikurangi dengan volume dari material penyangga. Perbandingan antara volume kerja efektif dengan volume total reaktor dapat dinyatakan sebagai persen porositas reaktor. Jika porositas besar maka pembentukan bentukan biofilm di material penyangga dapat berjalan dengan baik dan tidak akan terganggu dengan adanya aliran. Volume kerja efektif dapat digunakan untuk menghitung waktu tinggal substrat (Hidarulic Retention Time/HRT). HRT dipengaruhi oleh volume total reaktor dan dapat dikatakan berbanding terbalik dengan laju pemberian substrat/umpan, sehingga apabila HRT besar maka debit umpan yang diolah menjadi kecil dan begitu pula sebaliknya HRT kecil maka 
limbah yang diolah semakin besar. HRT pada pengolahan limbah cair organik secara anaeorobik mempengaruhi pembetukan hidrogen dan produksi gas metana ${ }^{(19)}$.

Selain beberapa hal yang telah diuraikan pada paragraf sebelumnya, ada beberapa faktor yang juga harus diperhatikan agar produksi biogas dan gas metana dalam pengolahan limbah cair industri tahu secara anerobik ini dapat menjadi lebih tinggi, diantaranya:

\section{Proses Inokulasi}

Tahap Inokulasi adalah proses memindahkan bakteri dari medium yang lama ke medium yang baru. Medium lama yang dimaksud pada proses inokulasi ini adalah cairan kotoran sapi yang selanjutnya akan di pindahkan ke medium baru yaitu reaktor anaerobik tipe Fixed Bed yang berisi material penyangga. Kotoran sapi dipilih karena mengandung poli bakteria dan didalamnya terdapat bakteri pembentuk gas metan. Pada proses ini harus diciptakan kondisi yang cukup baik untuk memungkinkan bakteri yang dimasukkan kedalam reaktor anaerobik tersebut dapat hidup dan berkembang biak. Kotoran sapi akan diinkubasi didalam reaktor anaerobik sampai kondisi stabil yaitu $\mathrm{pH}$ normal dan kandungan metan diatas $60 \%$. Proses inkubasi ini bertujuan agar terbentuknya lapisan tipis/biofilm pada permukaan potongan bambu. Biofilm tersebut adalah indikasi bahwa bakteri sudah melekat dengan sempurna. Proses inokulasi biasanya terjadi selama 1 sampai dengan 3 bulan ${ }^{(17)}$. Proses biodegradasi secara anaerobik yang melibatkan bakteri-bakteri inokulum dapat mempengaruhi beberapa parameter diantaranya $\mathrm{pH}$, terbentuknya biogas, dan gas metana ${ }^{(20)}$. Parameter $\mathrm{pH}$ yang diukur berasal dari effluent pengolahan limbah cair tahu. Pengamatan harian $\mathrm{pH}$ ini bertujuan untuk mengetahui kondisi kestabilan bakteri yang berada di dalam reaktor anaerobik. Umumnya bakteri dapat tumbuh maksimum antara $\mathrm{pH} 6-7,5^{(20)}$. Jika $\mathrm{pH}$ lebih rendah dari 5,0 dan lebih tinggi dari 8,5 maka pertumbuhan bakteri dapat terhambat meskipun ada beberapa pengecualian mikroba yang dapat hidup pada rentang $\mathrm{pH}$ tersebut. Setelah proses inokulasi berjalan dengan baik, maka dapat dilakukan pengisian substrat ke dalam reaktor sesuai dengan laju beban yang dinginkan.

2. Proses adaptasi atau pemberian umpan limbah cair industri tahu
Setelah proses inokulasi berjalan dengan baik, kemudian reaktor tersebut diadaptasikan secara anaerobik dengan limbah cair industri tahu secara berkesinambungan dimulai dari jumlah kecil hingga jumlah yang tinggi. Pengambilan limbah cair industri tahu dilakukan setiap hari untuk mendapatkan substrat yang segar dan dihrapkan belum terjadi degradasi. Pengsian limbah cair tahu dimulai dari $5 \%$ volume kerja efektif yang akan dioperasikan, dan selanjutnya kenaikan umpan dilakukan sekitar $10 \%$ per hari dari pengumpanan sebelumnya. Pada setiap kenaikan laju beban akan dilakukan pengamatan lapangan harian untuk mengamati kestabilan reaktor diantaranya; $\mathrm{pH}$, produksi biogas yang dihasilkan dan persen kandungan metana. Kondisi dikatakan stabil apabila jika dilakukan pengisian umpan, produksi gas akan bertambah, namun $\mathrm{pH}$ dan persen metan tidak turun. Apabila salah satu indikator ini menunjukkan penurunan, hal ini menandakan proses di dalam digester sudah terganggu dan dan apabila dua dari tiga indikator ini mengalami penurunan maka jumlah pengisian harus dikurangi atau dihentikan. Selain pengamatan langsung di lapangan, untuk mengetahui kemampuan kinerja atau effisiensi reaktor anaerobik tipe Fixed Bed ini dalam menurunkan kandungan organik limbah cair industri tahu, maka perlu dilakukan analisa laboratorium pada limbah cair tahu sebelum dan sesudah pengolahan. Analisa laboratorium yang dilakukan adalah mencari nilai kandungan COD sesuai dengan SNI 06-6989.15-2004.

\section{HASIL DAN PEMBAHASAN}

Reaktor anaerobik tipe Fixed Bed dan gasholder tipe floating ini dibuat dengan menggunakan bahan dari fiber glass, dipilihnya bahan ini karena fiberglass mudah dibentuk, tahan terhadap asamnya limbah cair tahu, tidak korosif, dan kuat. Kapasitas total reaktor anaerobik yang dibangun untuk pengolahan limbah cair tahu ini adalah sebesar $43 \mathrm{~m}^{3}$ dan kapasitas gas holder adalah sebesar $27 \mathrm{~m}^{3}$. Pada proses pengoperasianya, pengolahan limbah cair tahu di industri tahu di CV. Promatun Aroyyan ini tidak membutuhkan energi untuk pompa karena limbahnya dapat mengalir secara gravitasi kearah reaktor anaerobik.

Reaktor anaerobik tipe Fixed Bed ini diisi dengan material penyangga berupa bambu yang telah dipotong-potong dan dimasukkan secara acak kedalam reaktor anaerobik. Pemotongan bambu dilakukan untuk memperluas daerah permukaan tempat pertumbuhan atau berkembang biaknya bakteri. 
Bambu dipilih sebagai material penyangga/ support material karena harganya murah dan mudah didapat di Indonesia. Berdasarkan pengukuran lapangan didapat volume efektif reaktor adalah $35 \mathrm{~m}^{3}$. Porositas reaktor yang diperoleh $81,4 \%$, dengan kata lain bambu menempati volume ruang di dalam reaktor sebesar $18,6 \%$.

Pengisian potongan bambu sebagai material penyanga didalam reaktor anaerobik ditunjukkan pada Gambar 2.

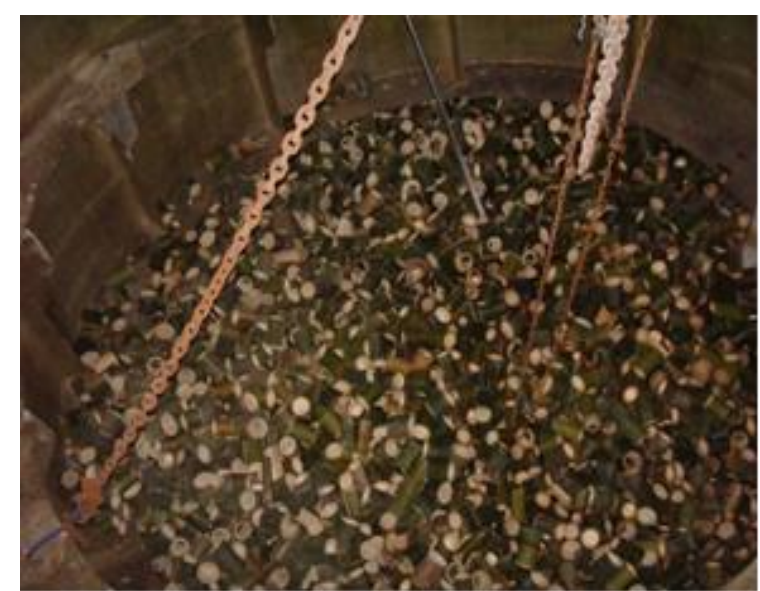

Gambar 2. Pengisian bambu sebagai material penyanga

Pengolahan limbah cair tahu di industri tahu dengan menggunakan reaktor anaerobik tipe Fixed Bed di CV. Promatun Aroyyan, Probolinggo dapat dilihat pada Gambar 3.

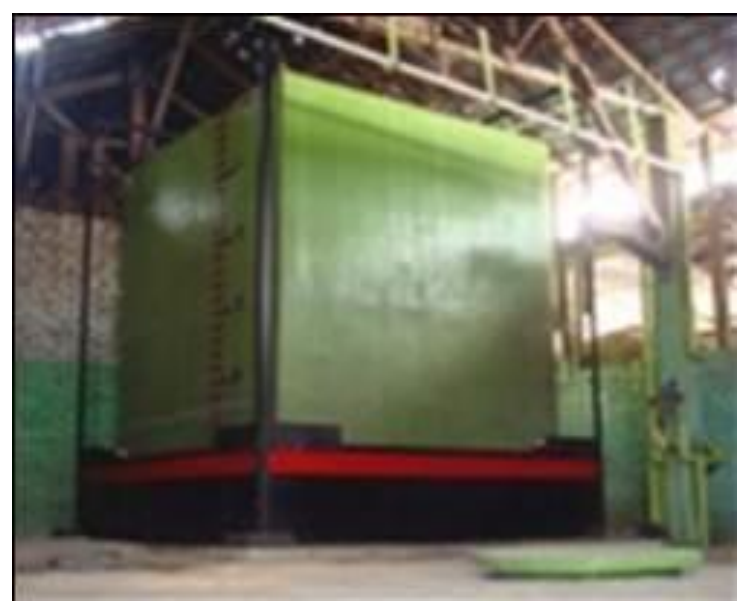

Gambar 3. Pengolahan limbah tahu dengan reaktor anaerobik tipe Fixed Bed di CV. Promatun Aroyyan

Pada proses inokulasi dilakukan pengisian kotoran sapi yang yang telah disaring dan ditambahkan dengan air dengan perbandingan 1:1. Penambahan campuran air kepada kotoran sapi ini di maksudkan untuk mempermudah kotoran sapi masuk kedalam reaktor. Cairan kotoran sapi tersebut diisi sampai penuh sesuai dengan volume efektif reaktor. Selanjutnya dilakukan inkubasi cairan kotoran sapi secara anaerobik di dalam reaktor hingga kondisi stabil. Pengamatan $\mathrm{pH}$ effluent dan \% kandungan metana yang dilakukan setiap hari selama proses inokulasi tersebut akan menunjukkan bahwa di dalam reaktor telah terjadi proses biodegradasi secara anaerobik.

Pengamatan selama proses inokulasi ditunjukkan pada Gambar 4.

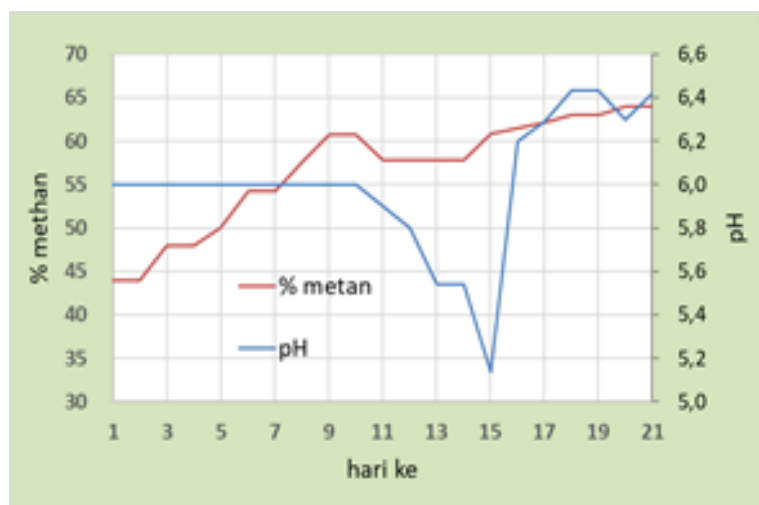

Gambar 4. Grafik pH starter dan persen metan selama proses inokulasi

Berdasarkan grafik pada Gambar 4. diatas menunjukan bahwa degrdasi bahan organik secara anaerobik telah berjalan dengan baik, yaitu ditandai dengan adanya penurunan $\mathrm{pH}$ sesaat pada hari ke 10 sampai dengan 15. Penurunan $\mathrm{pH}$ ini terjadi karena adanya tahap asidogenesis di sistem anaerobik, dimana senyawa-senyawa organik pada limbah cair industri tahu akan didegradasi oleh bakteri anaerob menjadi asam-asam lemak. Konsentrasi asam lemak yang tinggi dapat menyebabkan turunnya $\mathrm{pH}$ di dalam reaktor. Asam-asam lemak yang dihasilkan hanya sebagai produk antara di dalam proses degradasi bahan organik secara anerobik, dan selanjutnya asam-asam lemak tersebut akan diuraikan kembali oleh bakteri anaerob untuk menjadi senyawa yang lebih sederhana yaitu biogas dan gas metana yang ditadai dengan $\mathrm{pH}$ kembali normal.

Jika $\mathrm{pH}$ tidak kembali dengan normal atau $\mathrm{pH}$ lebih rendah dari 5,0 dan lebih tinggi dari 8,5 maka dapat dipastikan bahwa kondisi reaktor tidak berjalan dengan baik, sehingga proses inokulasi harus diulang. Tingginya kandungan volatile fatty acidNFA dapat menghambat jalannya produksi gas metana(21). Pada proses pengolahan secara anaerobik, jika VFA jauh melebihi batas maksimum maka maka dapat menyebabkan rusaknya sistem biologi didalam pengolahan limbah secara anaerobik. Kebanyakan beberapa produk yang dihasilkan dari pengolahan anaerobik dapat bersifat racun 
bagi konsorsium metanaogenik(22). Senyawa penghambat diantaranya yaitu amonia, sulfida, ion logam, dan logam berat ${ }^{(23)}$.

Berdasarkan grafik proses inokulasi pada Gambar 4 diatas, setelah hari ke 15 kondisi $\mathrm{pH}$ cenderung mengalami kenaikan kembali. Kondisi $\mathrm{pH}$ berada diatas angka 6 dan metan diatas $60 \%$ terjadi pada hari ke 16 . Hal ini menandakan bahwa sistem anaerobik mulai berjalan ke kondisi stabil, dimana bakteri pada proses metanogenesis telah mampu beradaptasi sehingga dapat mendegradasi asam-asam lemak organik menjadi gas metana. Selain itu, persentase gas metan yang dihasilkan menunjukan angka diatas $60 \%$, hal ini menandakan bahwa proses inokulasi di dalam reaktor anaerobik telah berjalan dengan baik, dimana populasi bakteri pembentuk asam lemak organik dan bakteri pembentuk metana mendapatkan nutrient yang cukup seimbang. Kondisi reaktor anaerobik yang stabil adalah tanda bahwa bakteri inokulum telah menempel dengan baik di permukaan material penyangga yang ditandai dengan terlihatnya lapisan tipis biofilm yang menempel pada potongan bambu. Selanjutnya, pada kondisi ini adaptasi pengisian limbah cair tahu sudah bisa mulai dimasukkan.

Pada tahap adaptasi, reaktor dioperasikan pada suhu kamar dan dan substrat secara terus menerus dan dialirkan masuk melalui bagian bawah reaktor dengan system up-flow dan efluent akan keluar melalui saluran efluen bagian atas reaktor. Kenaikan volume limbah cair industri tahu diberikan secara bertahap ke dalam reaktor anaerobik tipe Fixed Bed. Pengsian limbah cair tahu dimulai dari volume 180 liter/hari atau sekitar 5\% dari volume kerja efektif yang akan dioperasikan, selanjutnya kenaikan pengisian umpan limbah cair tahu ditambah sekitar $10 \%$ per hari dari pengumpanan sebelumnya. Kenaikan pengisian dapat dilanjutkan apabila kondisi reaktor dianggap stabil. Kestabilan reaktor anaerobik dapat dilihat dengan melakukan pengamatan harian yaitu kestabilan $\mathrm{pH}$, produksi biogas dan persentase kandungan gas $\mathrm{CH}_{4}$. Hasil pengamatan selama proses adaptasi ditunjukkan pada Gambar 5 dan Gambar 6.

Pada Gambar 5 dapat dilihat selama pengisian hari pertama sampai hari ke 39 , produksi gas/biogas cenderung terus meningkat dengan meningkatnya jumlah umpan yang dimasukkan, dan persentase kandungan metan dalam biogas bergerak dikisaran 61 - $70 \%$, dengan rata-rata kandungan $\mathrm{CH}_{4}$ sebesar $65 \%$.

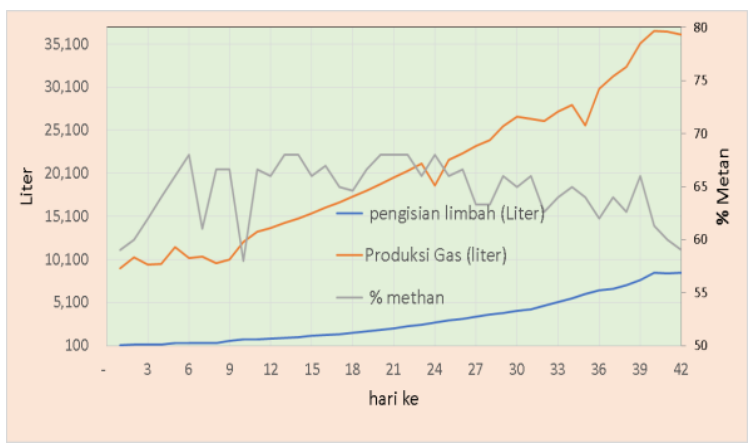

Gambar 5. Grafik hasil produksi biogas dan \% metana berbanding dengan jumlah pengisian limbah pada pengamatan proses adaptasi

Hal ini menunjukkan bahwa asam lemak organik yang terbentuk dapat dimanfaatkan dengan baik oleh bakteri pembentuk metan. Setelah hari ke 39 sampai hari ke 42 , persentase gas metan terus menurun. Begitu juga pada Gambar 6, dapat dilihat bahwa pergerakan $\mathrm{pH}$ terlihat stabil dan konstan dikisaran $6.4-6.8$. Kondisi $\mathrm{pH}$ terlihat turun setelah pengumpanan hari ke 36 sedikit naik di hari ke 38 , akan tetapi terus turun setelah hari ke 39.

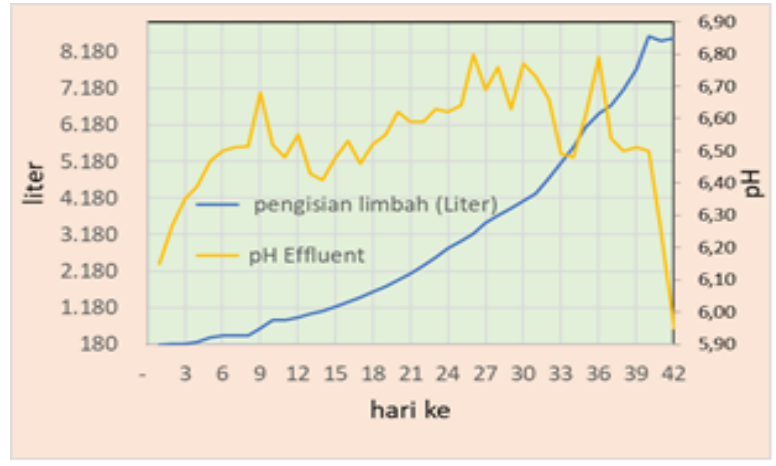

Gambar 6. Grafik hasil pH effluent berbanding dengan jumlah pengisian limbah pada pengamatan proses adaptasi

Berdasarkan kedua grafik pengamatan proses adaptasi yaitu Gambar 5 dan Gambar 6, terlihat bahwa pada hari ke 40, ketika umpan limbah cair tahu kembali dinaikkan maka terjadi perubahan stabilitas reaktor, yang ditandai dengan menurunnya nilai $\mathrm{pH}$, produksi biogas, persentase gas metana, menandakan bahwa kemampuan reaktor untuk menerima beban sudah melampaui batas maksimum. Hal ini terjadi karena meningkatnya jumlah substrat yang diberikan menyebabkan proses hidrolisis dan pengasaman menjadi tidak seimbang dibandingkan dengan proses pembentukan gas metana, sehingga membuat $\mathrm{pH}$ reaktor menjadi menurun ke arah asam. Pertumbuhan bakteri yang memproduksi asam tidak seimbang dibandingkan dengan populasi bakteri metana. 
Pengaruh laju beban yang semakin meningkat melebihi batas maksimum ini juga dapat membuat bakteri shock sehingga mengakibatkan terjadinya wash out atau keluarnya biomassa mikroba dari reaktor dan terbawa aliran effluent. Selain itu proses reaksi oksidasi anaerobik asam lemak rantai panjang dan oksidasi anaerobik produk antara (asamasam lemak organik) lebih cepat dibandingkan dengan konversi asam-asam lemak menjadi metana. Oleh karena itu dapat disimpulkan batas maksimal pengisian beban terjadi pada hari ke 39 dengan jumlah umpan sebesar 7.700 liter, waktu tinggal 4,5 hari, nilai $\mathrm{pH}$ masih dalam kondisi normal yaitu 6,5 , produksi biogas yang dihasilkan 35.158 liter atau setiap satu $\mathrm{m}^{3}$ limbah cair tahu yang diolah menghasilkan 4,6 $\mathrm{m}^{3}$ biogas, dan kandungan persen metana adalah $66 \%$.

Pada tahap adaptasi, secara parallel juga dilakulan pengujian laboratorium untuk mengetahui efisiensi reaktor anaerobik dalam menurunkan kandungan organik pada limbah cair industri tahu yang dihasilkan oleh CV. Promatun Aroyyan, Probolinggo. Pengujian limbah cair dilakukan pada limbah cair industri tahu sebelum diolah dan limbah cair industri tahu yang sudah diolah /effluent hasil dari reaktor anaerobik tipe Fixed Bed. Rata-rata hasil analisa kandungan organik pada limbah tahu sebelum diolah dan sesudah diolah dapat dilihat pada Tabel 1.

Tabel 1. Hasil Analisis limbah cair industri tahu CV. Promatun Aroyyan, Probolinggo

\begin{tabular}{cccc}
\hline \multirow{2}{*}{ No } & Parameter & \multicolumn{2}{c}{ Nilai rata - rata } \\
\cline { 3 - 4 } & $\begin{array}{c}\text { Sebelum } \\
\text { diolah }\end{array}$ & $\begin{array}{c}\text { Setelah } \\
\text { diolah }\end{array}$ \\
\hline 1. & $\mathrm{COD}(\mathrm{mg} / \mathrm{l})$ & 6.695 & 823 \\
\hline 2 & $\mathrm{pH}$ & 4,3 & 6,5 \\
\hline
\end{tabular}

Dari hasil analisa laboratorium yang disajikan pada Tabel 1, dapat diketahui kinerja reaktor anaerobik tipe Fixed Bed ini mempunyai efisiensi untuk mendegradasi $\mathrm{COD}$ adalah $87,7 \%$. Efisiensi kinerja reaktor ini sangat mempengruhi jumlah biogas yang dihasilkan, karena pembentukan biogas sangat bergantung pada komposisi kimia substrat atau COD yang didegradasi. Degradasi $1 \mathrm{~g}$ COD menghasilkan 0,35 liter gas metana ${ }^{(24)}$.

Berdasarkan data-data pada titik optimum pengukuran di hari ke 39 maka dapat dihitung bahwa $1 \mathrm{~g}$ COD dapat menghasilkan 0,51 liter gas metana. Hal ini menunjukkan bahwa gas metana yang dihasilkan dengan reaktor anaerobik tipe Fixed Bed ini lebih besar dari standar teori gas metana yang dapat terdegradasi.

\section{KESIMPULAN}

Dari hasil penelitian pengolahan limbah cair industri tahu dengan reaktor anaerobik di kota probolinggo kinerja optimal dari reaktor tipe Fixed Bed dan bambu sebagai material penyangga dicapai pada kondisi sebagai berikut:

a. Pembangunan dan instalasi reaktor anaerobik Fixed Bed berbahan fiberglass dengan kapasitas $43 \mathrm{~m}^{3}$, gas holder kapasitas $27 \mathrm{~m}^{3}$ dan volume efektif reaktor adalah $35 \mathrm{~m}^{3}$.

b. Proses inokulasi menggunakan cairan kotoran sapi membutuhkan waktu 16 hari.

c. Waktu tinggal limbah cair didalam reaktor (HRT) adalah 4,5 hari

d. volume produksi biogas maksimum yang dihasilkan dari pengolahan limbah cair tahu ini adalah 35.158 liter/hari

e. Rata-rata nilai kandungan gas metana adalah $65 \%$

f. Rata - rata COD dalam limbah cair sebelum diolah $6.695 \mathrm{mg} / \mathrm{l}$ dan COD limbah setelah diolah $823 \mathrm{mg} / \mathrm{l}$ atau efisiensi pengolahan $87,7 \%$.

g. Rata - rata $\mathrm{pH}$ limbah cair sebelum diolah 4,3 dan $\mathrm{pH}$ limbah setelah diolah $6,5 \mathrm{mg} / \mathrm{l}$

h. $1 \mathrm{~g}$ COD dapat menghasilkan 0,51 liter gas metana

Kondisi kinerja optimum pada proses adaptasi limbah cair industri tahu ini telah tercapai, namun masih belum memenuhi syarat baku mutu Permen LH No 5 tahun 2014. Oleh karena itu, untuk dapat memenuhi persyaratan baku mutu limbah cair yang telah ditetapkan maka masih diperlukan perlakuan lanjutan berupa pengolahan limbah dengan sistem aerobik.

\section{PERSANTUNAN}

Penulis menyampaikan terima kasih kepada Bapak Joko Prayitno Susanto selaku Direktur Pusat Teknologi Lingkungan BPPT, Dr. Drs. Suyud Warno Utomo, M.Si selaku dosen pembimbing II yang telah memberi bimbingan dan kesempatan untuk melakukan penelitian ini serta Badan Lingkungan Hidup Kota Probolinggo yang telah membiayai untuk terlaksananya penelitian ini.

\section{DAFTAR PUSTAKA}

1. Prasetiyadi, Indriyati. (2003). Pengolahan Limbah Cair Industri Tahu menjadi Biogas. 
Jakarta. Pusat Teknologi Lingkungan, Kedeputian TPSA-BPPT.

2. Nurhasan, A. dan Pramudyanto, B. D. (1997). Penanganan air limbah industri tahu. Semarang. Yayasan Bina Karya Lestari dan Wahana Lingkungan Hidup Indonesia.

3. Shafitri, Lidya Rahma. (2011). Internalisasi Biaya Eksternal Pengolahan Limbah Tahu (Studi kasus: Desa Kalisari Kecamatan Cilongok, Purwokerto). Departemen Ekonomi Sumberdaya dan Lingkungan. Skripsi. Fakultas Ekonomi dan Manajemen Institut Pertanian Bogor.

4. -------, Peraturan Pemerintah Kementerian Lingkungan Hidup No. 5 Tahun 2014 tentang Baku Mutu Air Limbah (BMAL).

5. Fitriyah, N. R. (2011). Studi Pemanfaatan Limbah Cair Tahu untuk Pupuk Cair Tanaman, Studi Kasus Pabrik Tahu Kenjeran. Surabaya: Teknik Lingkungan.

6. Kim, D. H., Lee, Y. D., \& Kim, M. S. (2011). Enhanced Biohidrogen Production From Tofu Residue By Acid/Base Pretereatment and Sewage Sludge Addition. Korea. Science Direct. International Journal of Hydrogen Energy 36. 13922-13927.

7. Alkyol, A. (2012). Treetment of Paint Manufacturing Wastewater by Electrocuagulation, Desalination Turkey. 285. 91-99. $9 \mathrm{hlm}$.

8. Siddharth, S. (2006). Green Energy Anaerobic Digestion. Proceedings of The 4th WSEAS Int. Conf. On Heat Transfer, Thermal Engineering And Environment, Elounda, Greece, August 21-23, Third Year Chemical Engineering. Sri Venkateswara College Of Engineering Sriperumbudur Anna University. Pp 276-280.

9. Hagos, K., Zong, J., \& Liu, D. L. C. (2016). Anaerobic co-digestion process for biogas production: Progress, challenges and perspectives. State Key Laboratory of Materials-Oriented Chemical Engineering, Nanjing Tech University, Nanjing 210009, China. Renewable and Sustainable Energy Reviews 2017 Vol.76 pp.1485-1496

10. Nurhadi. (2010). Evaluasi Kinerja Reaktor Upflow Anaerobic Sludge Blanket (ASB) dan Downflow Hanging Sponge (DHS) dalam Mengolah Air Limbah Domestik: Kajian Terhadap Kualitas Air Waduk Setiabudi Jakarta Selatan. Tesis. Universitas Indonesia.

11. Stams, A.J.M., Elfrink, S.J.W.H.O., \& Westerman, P. (2003). Metabolic Interactions Between Metanaogenic Consortia and Anaerobic Respiring Bacteria. Wageningen. School of Engineering and Applied Science, Civil and Environmental Engineering Dept. Advances in Biochemical
Engineering/ Biotechnology, Vol.

81. Springer.

12. Weiland, P. (1987). Development of anerobic filters for treatment of high strength agro industrial waste water. Bio Process Engineering, 2, 39 - 47, Springer - verlag.

13. Cakir, Stenstrom. (2005). Greenhouse gas production: A comparison between aerobic and anaerobic wastewater treatment technology. Water Research Volume 39, Issue 17. Pages 4197-4203.

14. Indriyati. (1997). Optimasi Pengolahan Limbah Cair Pabrik Kecap Secara Biologi menggunakan Reaktor tipe Fixed Bed. Tesis. Universitas indonesia. Jakarta: xiv + $103 \mathrm{hlm}$.

15. Nawawi, Hadari,. (1995). Instrumen Penelitian Bidang Sosial. Yogyakarta: Gadjah Mada University Press.

16. Cao, Wenping., Zhang, Houhu., Wang, Yinmei., Pan, JiZheng. (2012). Bioremediation of Polluted surface water by using biofilms on filamentous bamboo. Ecological engineering 42. 146-149.

17. Feng, Huajun., Hu, Lifang., Mahmood, Qaisar, Quu, Caidi., Fang, Chengran., Shen, Dongsheng. (2008). Anaerobic domestic wastewater teratment with bamboo carrier anaerobic baffled reactor. International Biodeterioration and Biodegradation 62 (18 June 2008) 232-238.

18. Wulfret, K. (1985). Two-phase Digester of Distillery Slops Using A. Fixed Bed Rector for Biomehanation. In : Palz, W : Coombs. J : Hall. D. O (Eds) : Energy From Biomass. Elsevier, p. 562, London, New York.

19. Dareioti, M.A., \& Kornaros, M. (2014). Effect of Hydraulic Retention Time (HRT) on Anaerobic Co-Digestion of Agro-Indutrial Wastes in a Two-Stage CSTR System. Greece. Bioresource Technology 167, Science Direct.

20. Stronach, S. M., Ruud, T., Lester J. N. (1986). Anaerobic Digestion Processess in Industrial Waste Water Treatment, Biotechnology Monographs, Springer Verlag, Berlin, Heidelberg.

21. Mazareli, Duda, Leite, dan Oliveira. (2016). Anaerobic co-digestion of vegetable waste and swine wastewater in high-rate horizontal reactors with fixed bed. Elsevier. Waste Management 52. 112-121.

22. Lins, Philipp., Reitschuler, Christoph., IImer, Paul. (2015). Impact of several antibiotics and 2-bromoethanesulfonate on the volatile fatty acid degradation, metanaogenesis and community structure during thermophilic anaerobic digestion. Bioresource Technology. Volume 190, Pages 148-158. 
23. Chen, Ye., Cheng, Jay J., Creamer, Kurt S. (2008). Inhibition of anaerobic digestion process: A review. Elsevier. Bioresource Technology. Volume 99, Issue 10, Pages 4044-4064.

24. Castrillon, P., Fernandez-Nava, Y., Ormaechea, \& Maranon, E. (2013). Metanae production from cattle manure supplemented with crude glycerin from the biodiesel industry in CSTR and IBR. Austria. Bioresource Technology 127. 312-317. 
